\title{
MESENCHYMAL STEM CELLS - A HISTORICAL OVERVIEW
}

\author{
Katarzyna Stefańska ${ }^{1}$, Rut Bryl ${ }^{1}$, Lisa Moncrieff ${ }^{1,2}$, Nelson Pinto $^{3}$, Jamil A. Shibli ${ }^{3}$, Marta \\ Dyszkiewicz-Konwińska ${ }^{4,5}$
}

\begin{abstract}
Mesenchymal stem cells are currently one of the most extensively studied topics in experimental medicine, given their unique properties in terms of immunomodulation, multiple factors secretion and homing to injured tissue sites. Such characteristics were proven to be invaluable in various disease management treatments, for example in cancer, tissue regeneration or immunologic/inflammatory-related disorders. MSCs were first isolated from bone marrow in 1960-1970's and were characterized as cells with fibroblastoid shape and osteogenic potential, which form clonogenic colonies (CFU-F - colony-forming unit-fibroblast). Nowadays the term 'mesenchymal stem cells' is used in regards to all of the cells meeting minimal criteria published in 2006 by the International Society for Cellular Therapy, however the name 'mesenchymal stromal cells' has been suggested to be more appropriate. Regardless of the name controversy, these cells exhibit multilineage differentiation potential, self-renewal ability, adhere to plastic and express specific surface antigens. In 2011 the first commercial product based on MSCs was developed and many more are expected to emerge. This review focuses on a historical perspective concerning studies on MSCs, controversies regarding their name and their characteristics and clinical utilization.
\end{abstract}

Running title: The history of mesenchymal stem cells

Keywords: mesenchymal stem cells, mesenchymal stromal cells, discovery, history

\footnotetext{
${ }^{1}$ Department of Histology and Embryology, Poznan University of Medical Sciences, Poznan, Poland

${ }^{2}$ The School of Medicine, Medical Sciences and Nutrition, University of Aberdeen, Aberdeen, United Kingdom

${ }^{3}$ Department of Periodontology and Oral Implantology, Dental Research Division, University of Guarulhos, Guarulhos, SP, Brazil

${ }^{4}$ Department of Biomaterials and Experimental Dentistry, Poznan University of Medical Sciences, Poznan, Poland

${ }^{5}$ Department of Anatomy, Poznan University of Medical Sciences, Poznan, Poland

* Correspondence: mdyszkiewicz@ump.edu.pl

Full list of author information is available at the end of article
} 


\section{Introduction}

As early as 1867 , Cohnheim observed that nonhematopoietic stem cells that could give rise to fibroblasts involved in the wound healing process were present in the bone marrow [1]. Among the first studies concerning the concept of mesenchymal stem cells (MSCs), the study conducted by Tavasolli and Crosby (1968) should be mentioned. These authors autologously transplanted fragments of bone marrow to extramedullary sites in rats, dogs and rabbits, and observed, that the cells contained within the bone marrow exhibited proliferative and osteoblastic potential, as indicated by osteoid tissue development [2]. This finding was undoubtedly relevant, since it indicated that there was a population of cells within the bone marrow that could develop into the bone, apart from the hematopoietic cell population. Such a discovery gave rise to subsequent studies concerning these stem cells' characteristics and Friedenstein was one of the pioneers in the field.

In 1970, Friedenstein and colleagues revealed that these cells from bone marrow with osteogenic potential differed from hematopoietic cells during in vitro culture. They were of fibroblastoid shape and adhered to culture vessels, forming clonogenic colonies termed colony-forming unit-fibroblast (CFU-F), and therefore their stromal origin was suggested [3]. The stromal origin of the colonies was confirmed with thymidine labelling, time-lapse photography and chromosome markers [3]. Subsequent studies revealed that when these cells were derived from bone marrow cultures, they were able to transform to bone and myeloid tissue after retransplantation under the kidney capsule. Similar results were observed when stromal precursors were derived from spleen cultures, resulting in reticular tissue populated with lymphoid cells formation [4]. It was therefore suggested that these stromal precursors were responsible for formation of the microenvironment of bone marrow or spleen after the transplantation. Moreover, in a study conducted in 1987, Friedenstein and colleagues revealed, that cells derived from bone marrow CFU-Fs were able to form cartilage after transplantation in diffusion chambers [5].

Owen and Friedenstein proposed in their paper from 1988, that aforementioned stromal stem cells most probably give rise not only to osteogenic and chondrogenic lineages, but to other cell lines as well, namely fibroblastic, reticular and adipocytic [6]. Besides this, they exhibited self-renewal potential by being able to regenerate bone tissue after implantation [6]. Importantly, the results described above indicated that differentiation capacity of these stromal cells was independent of their microenvironment and structural interactions. In 1999 Pittenger et al. [7] confirmed multilineage differentiation potential of mesenchymal cells from bone marrow by obtaining adipocytes, chondroblasts and osteoblasts in vitro, under appropriate stimuli. Moreover, in the same year, Kopen and colleagues demonstrated that MSCs were able to differentiate into astrocytes after injection into neonatal mouse brain, therefore indicating that these cells also have the capability to differentiate into ectoderm-derived tissues [8].

\section{Mesenchymal stem cells}

In the paper from 1987 (mentioned earlier) by Friedenstein et al. [5], the authors termed these stromal cells 'bone marrow osteogenic stem cells'. However, taking the properties and characteristics of these cells into consideration, 'mesenchymal stem cells' was also coined and the first one to use it in regards to bone marrow stromal cells was Caplan, in his paper published in 1991 [9]. Mesenchymal stem cells were described as cells with no limitation in terms of specific number of mitotic division and possessing ability to differentiate into various types of cells, in response to both paracrine regulation and autocrine signaling. Mesenchymal stem cells found in the embryo are considered pluripotent and can give rise to tissues like bone, cartilage, tendon, ligament, marrow stroma, adipocyte, dermis, muscle and connective tissue in general [9]. The term 'mesenchymal' is derived from Greek and means 'middle' - in concerns to the middle primary germ layer - the mesoderm. Mesenchymal stem cells were demonstrated to be present in marrow, periosteum and muscle connective tissue [9].

Although the term 'mesenchymal stem cells' was generally accepted by the scientific society and is used on a regular basis, some authors were concerned whether it is accurate. Bianco et al. [10] suggested that it was inappropriate since the differentiation capacity of mesenchymal stem cells was questionable and naming them 'stem' led to the assumption that they indeed possess such abilities. Moreover, bone develops from neuroectodermal progenitors and even though such cells may possess properties of mesenchymal stem cells, naming them 'mesenchymal' would be inadequate [10].

Nowadays the term 'mesenchymal stem cells' not only refers to stromal cells derived from bone marrow, but also to the cells from various other connective tissue sources. Additionally, the abbreviation of this term (MSCs) may be understood in different ways, such as 'multipotent stromal cells', 'multipotent stem cells', 'mesenchymal stromal cells' etc., therefore it is important to remember that this name is rather unclear [11]. The International Society for Cellular Therapy suggested the clarification for this nomenclature in their position statement from 2005 [12]. They suggested using the term 'mesenchymal stem cells' only in regards to the cells meeting specific stem cell criteria, while the cells that are plastic-adherent and of fibroblast-like shape should be named 'multipotent mesenchymal stromal cells' [12]. 
However, in 2010, Caplan proposed another way to expand the abbreviation MSCs - namely 'medicinal signaling cells', due to the secretory properties of these cells, which was relevant in terms of disease treatments [13].

\section{Defining mesenchymal stem cells/ mesenchymal stromal cells}

Taking the above statement into the consideration, the International Society for Cellular Therapy issued a set of minimal criteria to define MSCs in the meaning of multipotent mesenchymal stromal cells, since there has been many inconsistencies in their characteristics among the investigators [14]. To date, such cells were isolated from tissues like: adipose tissue [15], dental pulp [16], endometrium [17], human breast milk [18], placenta [19], amniotic fluid [20,21], umbilical cord blood [22], Wharton's jelly [23] and many others. In order to ensure that the results obtained by different scientific groups could be compared, they stated that the cells considered MSCs should:

- $\quad$ adhere to plastic in standard culture conditions using tissue culture flasks,

- $\quad$ exhibit specific surface marker expression; $>95 \%$ cells must be positive for CD105 (endoglin), CD73 (5'-nucleotidase) and CD90 (Thy-1); besides, these cells must not express CD45 (protein tyrosine phosphatase, receptor type, C), CD34, CD14, CD11b (integrin alpha-M), CD79a (MB-1 membrane glycoprotein), CD19 (B lymphocyte surface antigen B4) and HLA-II (human leukocyte antigen class II),

- be able to differentiate into osteoblasts, adipocytes and chondroblasts in vitro [14].

They additionally suggested, that differentiation towards osteoblasts should be confirmed with Alizarin Red or von Kossa staining, adipocytic differentiation with Oil Red 0 staining, while chondroblast differentiation with Alcian Blue or immunohistochemical staining [14]. However, it is important to remember that these criteria would apply only to human MSCs, since the surface antigen expression profile may be different in other species.

Besides aforementioned antigens, several others have been proposed to identify MSCs. One of them, STRO-1, was brought to attention as early as in 1991 by Simmons et al., who reported that clonogenic bone marrow stromal cells could be enriched while using it [24]. Another marker used for this purpose was CD146 (MCAM) [25].

\section{MSCs in vivo}

In adult organisms, the presence of stem cells becomes restricted to a specialized microenvironment - a 'niche', which is responsible for external signals controlling the fate of stem cells [26]. In the niche, the destiny of stem cells is dependent on fac- tors secreted by the surrounding cells, such as TGF $\beta$ or Wnt, as well as on the direct cell-to-cell contact mediated by integral membrane proteins. Adhesion to the extracellular matrix plays an important role in stem cell fate determination as well, mostly via interaction through integrins [26]. Importantly, in bone marrow, MSCs themselves comprise the niche for hematopoietic stem cells, regulating the hematopoietic process [27].

As it was previously mentioned, MSCs are assumed to be derived from mesenchyme - an embryonic connective tissue, that spreads throughout the embryo during its development. However, the exact origin of MSCs remains elusive. Some authors even suggested that MSCs gain their properties during an in vitro culture, with no in vivo counterpart [28]. However, based on expression of specific genes, such as vimentin, fibronectin or osteopontin in bone marrow stromal cells, the assumption has been made that they are derived from embryonic mesodermal cells, as they share these characteristics [29]. On the other hand, Takashima et al. demonstrated in 2007, that the earliest wave of MSCs in the embryonic trunk was derived from Sox1+ neuroepithelium, in part through neural crest intermediate stage [30]. Since during the further development these cells were shown to be replaced by MSCs from unknown sources, the conclusion from this study was that MSCs in vivo are derived from multiple developmental origins [30].

Considering that MSCs give rise to osteoblasts, chondroblasts and adipocytes, which are located throughout the entire organism, it has been suggested that MSCs are in a relationship with perivascular cells, providing an explanation why they can be obtained from various vascularized tissues [31]. The fact that the pericytes were shown to differentiate into mesenchymal stem cell types in vitro is definitely in favor of this hypothesis, suggesting that the pericytes serves as a reservoir of progenitor cells being able to differentiate towards osteoblasts, chondroblasts or adipocytes [32].

\section{MSCs in disease treatments}

Although the exact origin of MSCs remains elusive, there has been a rapid development in their clinical utilization. This is due to the fact of their massive immunomodulatory properties (reviewed by [33], among others). They also secrete factors such as enzymes, growth factors, cytokines, chemokines and many others, influencing their environment in a paracrine manner [34]. MSCs are also able to selectively home to injured tissues, probably due to the increase of the inflammatory factors levels [35].

The first clinical trial utilizing MSCs was conducted in 1995 by Lazarus and colleagues [36]. They expanded in culture MSCs, which were named 'mesenchymal progenitor cells' derived from the human bone marrow of patients with hematologic malig- 
nancies in complete remission. After in vitro cultivation, the autologous cells were administered intravenously to patients and no adverse effects were observed, indicating that such a therapy would be safe [36]. Since this first trial, many others were conducted and completed. After a search on clinicaltrials.gov database with the term 'MSC', 9173 results were obtained, proving that this area of medicine is rapidly growing and evolving. In 2011 the first commercial product with the use of MSCs, Cartistem ${ }^{\circledR}$ was developed and it was reported to be used in cartilage regeneration in osteoarthritic patients by Park and colleagues in 2016 [37].

Given the unique properties of MSCs, it seems that regenerative medicine would benefit the most from their utilization. Indeed, these cells were used multiple times in facilitating bone regeneration and fracture repair [38], cartilage regeneration [39], lung regeneration [40], wound healing, for example in burns or diabetes [41] and many others. Also, MSCs were proven to be useful in the case of cancer, since they exhibit tumor trophic properties and therefore may be used as vehicles releasing antitumorigenic molecules [42]. Since MSCs exhibit such vast immunomodulatory properties, it is impossible not to mention their utility in immunologic/inflammatory-related disorders, such as graft-versus-host disease [43], multiple sclerosis [44], osteoarthritis [45], rheumatoid arthritis [46], inflammatory bowel disease and Crohn's disease [47].

\section{Conclusions}

Mesenchymal stem cells or mesenchymal stromal cells have emerged as an indispensable tool in regenerative medicine. The reflection of that is the number of registered clinical trials and papers on this subject, proving that this is one of the most rapidly evolving field of current experimental medicine. They are utilized in various disease managements, from cancer to immunologic/inflammatory-related disorders, and are often the last chance for improvement of a patient's condition when other therapies fail. However, all the positive outcomes reported should be treated with caution. Although the origin of MSCs and their in vivo anatomical localization remain elusive and there has been some concerns regarding the accuracy of their name, the minimal criteria for their definition in vitro has been published and allowed tremendous growth in this field. There is no doubt, that further investigation should be conducted in terms of MSCs origin, in order to ensure that all the studies published are replicable and reliable.

\section{Ethical approval}

The conducted research is not related to either human or animal use.

\section{Acknowledgments}

This publication and its results are an outcome of a cooperation between Poznan University of Medical Sciences (Poznań, Poland) and Polish Ministry of Science and Higher Education, with Cellivia 3 SA (Poznań, Poland), as a part of the "Professional PhD" program.

\section{Corresponding author}

Marta Dyszkiewicz-Konwińska, Department of Biomaterials and Experimental Dentistry, Poznań University of Medical Sciences, 70 Bukowska St., 60-812 Poznań, Poland and Department of Anatomy, Poznań University of Medical Sciences, 6 Święcickiego St., 60-781 Poznań, Poland, Tel./Fax: +48 61 8546565, e-mail: mdyszkiewicz@ump.edu.pl.

\section{Conflicts of interest statement}

The authors declare they have no conflict of interest.

\section{References}

1. Chamberlain G, Fox J, Ashton B, Middleton J. Concise review: mesenchymal stem cells: their phenotype, differentiation capacity, immunological features, and potential for homing. Stem Cells. 2007; DOI:10.1634/ stemcells.2007-0197.

2. Tavassoli M, Crosby WH. Transplantation of marrow to extramedullary sites. Science (80- ). 1968; DOI:10.1126/science.161.3836.54.

3. Friedenstein AJ, Chailakhjan RK, Lalykina KS. The development of fibroblast colonies in monolayer cultures of guinea-pig bone marrow and spleen cells. Cell Prolif. 1970;3:393-403; DOI:10.1111/j.1365-2184.1970.tb00347.x.

4. Friedenstein AJ, Chailakhyan RK, Latsinik N V., Panasyvk AF, Keiliss-Borok I V. Stromal cells responsible for transferring the microenvironment of the hemopoietic tissues: Cloning in vitro and retransplantation in vivo. Transplantation. 1974; DOI:10.1097/00007890-197404000-00001.

5. Friedenstein AJ, Chailakhyan RK, Gerasimov U V. Bone marrow osteogenic stem cells: in vitro cultivation and transplantation in diffusion chambers. Cell Prolif. 1987; DOI:10.1111/j.1365-2184.1987.tb01309.x.

6. Owen M, Friedenstein AJ. Stromal stem cells: marrow-derived osteogenic precursors. Ciba Found Symp. 1988.

7. Pittenger MF, Mackay AM, Beck SC, Jaiswal RK, Douglas R, Mosca JD, Moorman MA, Simonetti DW, Craig S, Marshak DR. Multilineage potential of adult human mesenchymal stem cells. Science (80- ). 1999; DOI:10.1126/science.284.5411.143.

8. Kopen GC, Prockop DJ, Phinney DG. Marrow stromal cells migrate throughout forebrain and cerebellum, and they differentiate into astrocytes after injection into neonatal mouse brains. Proc Natl Acad Sci U S A. 1999; DOI:10.1073/pnas.96.19.10711.

9. Caplan AI. Mesenchymal stem cells. J Orthop Res. 1991; DOI:10.1002/ jor.1100090504.

10. Bianco P, Robey PG, Simmons PJ. Mesenchymal stem cells: revisiting history, concepts, and assays. Cell Stem Cell. 2008; DOI:10.1016/j. stem.2008.03.002.

11. Andrzejewska A, Lukomska B, Janowski M. Concise review: mesenchymal stem Cells: from roots to boost. Stem Cells. 2019; D0I:10.1002/ stem.3016.

12. Horwitz EM, Le Blanc K, Dominici M, Mueller I, Slaper-Cortenbach I, Marini FC, Deans RJ, Krause DS, Keating A. Clarification of the nomenclature for MSC: The International Society for Cellular Therapy position statement. Cytotherapy. 2005; DOI:10.1080/14653240500319234.

13. Caplan AI. What's in a Name? Tissue Eng - Part A. 2010; DOI:10.1089/ ten.tea.2010.0216

14. Dominici M, Le Blanc K, Mueller I, Slaper-Cortenbach I, Marini FC, Krause DS, Deans RJ, Keating A, Prockop DJ, Horwitz EM. Minimal criteria for defining multipotent mesenchymal stromal cells. The International Society for Cellular Therapy position statement. Cytotherapy. 2006;8:3157; DOI:10.1080/14653240600855905.

15. Katz AJ, Tholpady A, Tholpady SS, Shang H, Ogle RC. Cell surface and transcriptional characterization of human adipose-derived adherent stromal (hADAS) cells. Stem Cells. 2005; DOI:10.1634/stemcells.2004-0021.

16. Seo BM, Miura M, Gronthos S, Bartold PM, Batouli S, Brahim J, Young M, Robey PG, Wang CY, Shi S. Investigation of multipotent postnatal stem cells from human periodontal ligament. Lancet. 2004; DOI:10.1016/ S0140-6736(04)16627-0.

17. Meng X, Ichim TE, Zhong J, Rogers A, Yin Z, Jackson J, Wang H, Ge W, Bogin V, Chan KW, Thébaud B, Riordan NH. Endometrial regenerative cells: A novel stem cell population. J Transl Med. 2007; DOI:10.1186/1479-5876-5-57

18. Patki S, Kadam S, Chandra V, Bhonde R. Human breast milk is a rich source of multipotent mesenchymal stem cells. Hum Cell. 2010; DOI:10.1111/j.1749-0774.2010.00083.x

19. In 't Anker PS, Scherjon SA, Kleijburg-van der Keur C, de Groot-Swings GMJS, Claas FHJ, Fibbe WE, Kanhai HHH. Isolation of mesenchymal stem 
cells of fetal or maternal origin from human placenta. Stem Cells. 2004; DOI:10.1634/stemcells.2004-0058.

20. In 't Anker PS, Scherjon SA, Kleijburg-van der Keur C, Noort WA, Claas FHJ, Willemze R, Fibbe WE, Kanhai HHH. Amniotic fluid as a novel source of mesenchymal stem cells for therapeutic transplantation. Blood. 2003;102:1548-9; DOI:10.1182/blood-2003-04-1291.

21. Roubelakis MG, Pappa KI, Bitsika V, Zagoura D, Vlahou A, Papadaki HA Antsaklis A, Anagnou NP. Molecular and proteomic characterization of human mesenchymal stem cells derived from amniotic fluid: Comparison to bone marrow mesenchymal stem cells. Stem Cells Dev. 2007; DOI:10.1089/scd.2007.0036.

22. Deasy BM, Schugar RC, Chirieleison SM, Wescoe KE, Schmidt BT, Askew Y, Nance JJ, Evron JM, Peault B. High harvest yield, high expansion, and phenotype stability of CD146 mesenchymal stromal cells from whole primitive human umbilical cord tissue. J Biomed Biotechnol. 2009;2009; DOI:10.1155/2009/789526.

23. Wang HS, Hung SC, Peng ST, Huang CC, Wei HM, Guo YJ, Fu YS, Lai MC, Chen CC. Mesenchymal stem cells in the Wharton's jelly of the human umbilical cord. Stem Cells. 2004;22:1330-7; DOI:10.1634/ stemcells.2004-0013.

24. Simmons PJ, Torok-Storb B. Identification of stromal cell precursors in human bone marrow by a novel monoclonal antibody, STRO-1. Blood. 1991; DOI:10.1182/blood.v78.1.55.bloodjournal78155.

25. Sacchetti B, Funari A, Michienzi S, Di Cesare S, Piersanti S, Saggio I, Tagliafico E, Ferrari S, Robey PG, Riminucci M, Bianco P. Self-renewing osteoprogenitors in bone marrow sinusoids can organize a hematopoietic microenvironment. Cell. 2007; DOI:10.1016/j.cell.2007.08.025.

26. Watt FM, Hogan BLM. Out of eden: Stem cells and their niches. Science (80- ). 2000; DOI:10.1126/science.287.5457.1427

27. Mitsiadis TA, Barrandon O, Rochat A, Barrandon Y, De Bari C. Stem cell niches in mammals. Exp Cell Res. 2007; DOI:10.1016/j. yexcr.2007.07.027.

28. Murray IR, West CC, Hardy WR, James AW, Park TS, Nguyen A, Tawonsawatruk T, Lazzari L, Soo C, Péault B. Natural history of mesenchymal stem cells, from vessel walls to culture vessels. Cell Mol Life Sci. 2014 DOI:10.1007/s00018-013-1462-6.

29. Dennis JE, Charbord P. Origin and differentiation of human and murine stroma. Stem Cells. 2002; DOI:10.1634/stemcells.20-3-205.

30. Takashima Y, Era T, Nakao K, Kondo S, Kasuga M, Smith AG, Nishikawa SI Neuroepithelial cells supply an initial transient wave of MSC differentiation. Cell. 2007; DOI:10.1016/j.cell.2007.04.028.

31. da Silva Meirelles L, Caplan AI, Nardi NB. In search of the in vivo identity of mesenchymal stem cells. Stem Cells. 2008; DOI:10.1634/ stemcells.2007-1122.

32. Doherty MJ, Ashton BA, Walsh S, Beresford JN, Grant ME, Canfield AE. Vascular pericytes express osteogenic potential in vitro and in vivo. Bone Miner Res. 1998; DOI:10.1359/jbmr.1998.13.5.828.

33. Shi Y, Wang Y, Li Q, Liu K, Hou J, Shao C, Wang Y. Immunoregulatory mechanisms of mesenchymal stem and stromal cells in inflammatory diseases. Nat Rev Nephrol. 2018; DOI:10.1038/s41581-018-0023-5.

34. Kupcova Skalnikova H. Proteomic techniques for characterisation of mesenchymal stem cell secretome. Biochimie. 2013; DOI:10.1016/j. biochi.2013.07.015

35. Yagi H, Soto-Gutierrez A, Parekkadan B, Kitagawa Y, Tompkins RG, Kobayashi N, Yarmush ML. Mesenchymal stem cells: Mechanisms of immunomodulation and homing. Cell Transplant. 2010 DOI:10.3727/096368910X508762.

36. Lazarus HM, Haynesworth SE, Gerson SL, Rosenthal NS, Caplan AI. Ex vivo expansion and subsequent infusion of human bone marrow-derived stromal progenitor cells (mesenchymal progenitor cells): Implications for therapeutic use. Bone Marrow Transplant. 1995.

37. Park Y-B, Ha C-W, Lee C-H, Yoon YC, Park Y-G. Cartilage regeneration in osteoarthritic patients by a composite of allogeneic umbilical cord blood-derived mesenchymal stem cells and hyaluronate hydrogel: results from a clinical trial for safety and proof-of-concept with 7 years of extended follow-up. Stem Cells Transl Med. 2017; DOI:10.5966/ sctm.2016-0157.

38. Wang X, Wang Y, Gou W, Lu Q Peng J, Lu S. Role of mesenchymal stem cells in bone regeneration and fracture repair: A review. Int Orthop. 2013; DOI:10.1007/s00264-013-2059-2.

39. Huang YZ, Xie HQ, Silini A, Parolini O, Zhang Y, Deng L, Huang YC. Mesenchymal stem/progenitor cells derived from articular cartilage, synovial membrane and synovial fluid for cartilage regeneration: current status and future perspectives. Stem Cell Rev Reports. 2017; DOI:10.1007/ s12015-017-9753-1.

40. Azargoon A, Negahdari B. Lung regeneration using amniotic fluid mesenchymal stem cells. Artif Cells, Nanomedicine Biotechnol. 2018; DOI:1 $0.1080 / 21691401.2017 .1337023$.
41. Maranda E, Rodriguez-Menocal L, Badiavas E. Role of mesenchymal stem cells in dermal repair in burns and diabetic wounds. Curr Stem Cell Res Ther. 2016; DOI:10.2174/1574888x11666160714115926.

42. Christodoulou I, Goulielmaki M, Devetzi M, Panagiotidis M, Koliakos G Zoumpourlis V. Mesenchymal stem cells in preclinical cancer cytotherapy: A systematic review. Stem Cell Res Ther. 2018; DOI:10.1186/ s13287-018-1078-8.

43. Le Blanc K, Rasmusson I, Sundberg B, Götherström C, Hassan M, Uzunel M, Ringdén 0 . Treatment of severe acute graft-versus-host disease with third party haploidentical mesenchymal stem cells. Lancet. 2004 DOI:10.1016/S0140-6736(04)16104-7.

44. Connick P, Kolappan M, Patani R, Scott MA, Crawley C, He XL, Richardson K, Barber K, Webber DJ, Wheeler-Kingshott CAM, Tozer DJ, Samson RS, Thomas DL, Du MQ, Luan SL, Michell AW, Altmann DR, Thompson AJ, Miller DH, Compston A, Chandran S. The mesenchymal stem cells in multiple sclerosis (MSCIMS) trial protocol and baseline cohort characteristics: An open-label pre-test: Post-test study with blinded outcome assessments. Trials. 2011; DOI:10.1186/1745-6215-12-62.

45. Emadedin M, Liastani MG, Fazeli R, Mohseni F, Moghadasali R, Mardpour S, Hosseini SE, Niknejadi M, Moeininia F, Fanni AA, Eslaminejhad RB, Dizaji AV, Labibzadeh N, Bafghi AM, Baharvand H, Aghdami N. Long-term follow-up of intra-articular injection of autologous mesenchymal stem cells in patients with knee, ankle, or hip osteoarthritis. Arch Iran Med. 2015.

46. Bouffi C, Djouad F, Mathieu M, Noël D, Jorgensen C. Multipotent mesenchymal stromal cells and rheumatoid arthritis: risk or benefit? Rheumatology (Oxford). 2009; DOI:10.1093/rheumatology/kep162.

47. Molendijk I, Bonsing BA, Roelofs H, Peeters KCMJ, Wasser MNJM, Dijkstra G, Van Der Woude CJ, Duijvestein M, Veenendaal RA, Zwaginga JJ, Verspaget HW, Fibbe WE, Van Der Meulen-De Jong AE, Hommes DW. Allogeneic bone marrow - derived mesenchymal stromal cells promote healing of refractory perianal fistulas in patients with Crohn's disease. Gastroenterology. 2015; DOI:10.1053/j.gastro.2015.06.014. 